\title{
SARS-CoV-2 peptide vaccine elicits T-cell responses in mice but does not protect against infection or disease
}

Victoria K. Baxter, Elizabeth J. Anderson, Sharon A. Taft-Benz, Kelly Olsen, Maria Sambade, Kaylee M. Gentry, Wolfgang Beck, Jason Garness, Allison Woods, Misha Fini, Brandon Carpenter, Christof C. Smith, Mark T. Heise, Benjamin Vincent, Alex Rubinsteyn

\section{Abstract}

There is significant interest in T-cell mediated immunity against SARS-CoV-2. Both vaccination and infection have been observed to elicit durable T-cell responses against the virus. The classical role of CD4+ T-cell responses in coordinating humoral immunity is well understood but it is less clear to what degree, if any, T-cell responses play a direct protective role against infection In this study we vaccinated BALB/c mice with peptides derived from the SARS-CoV-2 proteome designed to either elicit T-cell responses or B-cell responses against linear epitopes. These peptides were administered in combination with either of two adjuvants, poly(l:C) and the STING agonist $\mathrm{BI}-1387466$. Both adjuvants consistently elicited responses against the same peptides, preferentially from the group selected for predicted T-cell immunogenicity. The magnitude of T-cell responses was, however, significantly higher with BI-1387466 compared with poly(I:C). Neither adjuvant group, however, provided any protection against infection with the murine adapted virus SARS-CoV-2-MA10 or from disease following infection.

\section{Introduction}

Strong and persistent T-cell responses to SARS-CoV-2 have been demonstrated across many studies of convalescent patients (1-4). These responses have been thought to play an important, albeit secondary, role in viral clearance and have also been measured as secondary endpoints in many trials of vaccines against SARS-CoV-2 (5-7). While CD4+ T-cell responses have a well understood role in the promotion of antibody responses(8), it is less clear whether T-cell responses independent of B-cells provide protection against infection with SARS-CoV-2 or attenuate disease severity. The small body of extant studies on this issue have reported contradictory results which also vary across animal models (9-12). 
Several studies have evaluated the role of SARS-CoV-2 specific T-cells in B-cell independent viral clearance and immunity. The most surprising of these has been Hasenkrug et al. (9), which showed that depleting the majority of CD4+ and nearly all CD8+ T-cells in rhesus macaques did not significantly alter the course of infection or symptoms of disease upon reinfection. On the other hand, a similar study by McMahan et al.(10) found that CD8+ T-cells did play an assistive role in viral clearance which is most evident when antibodies are absent and/or insufficiently neutralizing.

Israelow et al(11) examined the relative roles of humoral and cellular immunity from both prior infection and vaccination in K18-hACE2 by a combination of depletion and transfer studies. Their findings confirm that neutralizing antibodies provide protection even in the absence of CD8+ T-cells. Conversely, transfer of SARS-CoV-2 specific CD8+ T-cells to Rag1 deficient mice, in the absence of humoral immunity, provided noticeable but incomplete protection from infection. A complementary study of nucleocapsid vaccination in Syrian hamsters and K18-hACE2 mice by Matchett et al.(12) showed T-cell mediated partial protection from severe disease.

Vaccines using synthetic peptides as antigens have a long and often unsuccessful history of use against pathogens. Peptide vaccines have been designed to target linear B-cell epitopes for pathogens such as FMDV (13), DENV (14, 15), and HIV (16) but are not typically are able to elicit significant numbers of neutralizing antibodies except in rare cases where a target a highly functional conserved linear epitope can be found on the surface of a viral receptor. Furthermore, antigenic peptides must either be conjugated to a carrier or are otherwise modified to improve valency and conformational stability $(17,18)$. Eliciting T-cell responses with peptide vaccination is more straight-forward, which has resulted in much interest in their use for therapeutic cancer vaccination $(19,20)$. In particular, adjuvants such as polyinosinic:polycytidylic acid and its derivative poly-ICLC have become commonly used for cancer vaccination in combination with synthetic peptides (21-24). There have been a few attempts at achieving protection from viral infection with T-cell directed peptide vaccines, such as for HIV (25) and EBOV (26), but experience with T-cell vaccines is much more limited than the rich body of work relating to achieving protective antibody responses.

In this study we use viral challenge following peptide vaccination to examine the potential for T-cell responses in the absence of neutralizing antibody responses to protect mice from infection with SARS-CoV-2-MA10 or disease subsequent to infection(27). The vaccine contains peptides selected for predicted T-cell immunogenicity, compared with a second group of peptides selected for antibody responses against linear epitopes. Peptide antigens are combined with either of two 
different adjuvants known for eliciting potent T-cell responses, poly(l:C)(28) and the STING agonist BI-1387466(29).

\section{Methods}

\section{Vaccine peptide selection}

Vaccine contents were selected in a previous publication (30), whose methods will be briefly summarized here. The protein sequences of the ancestral Wuhan-1 SARS-CoV-2 strain were analyzed for candidate linear B cell epitopes along with predicted human $\mathrm{T}$-cell epitopes which coincide with murine $\mathrm{MHC}$ ligands. B-cell epitope regions were chosen from linear epitope mapping studies of convalescent patient serum, followed by computational filtering for predicted surface accessibility, sequence conservation, spatial localization near annotated functional domains of the spike protein, and avoidance of glycosylation sites. T-cell epitopes were derived in a purely computational manner, starting with $\mathrm{MHC}$ binding predictions across a variety of high frequency HLA alleles. These predicted MHC ligands were further filtered by predicted immunogenicity, sequence conservation, and source protein abundance. 27 mer vaccine peptides were selected to optimize the number of adjacent predicted T-cell epitopes, predicted murine $\mathrm{MHC}$ ligands for the $\mathrm{H} 2-\mathrm{b}$ and $\mathrm{H} 2-\mathrm{d}$ haplotypes, along with in silico prediction of manufacturability. The selection process ultimately yielded 22 candidate vaccine peptides, which were manually curated to 16 sequences in order to eliminate redundancy between highly overlapping sequencing.

\section{Mouse vaccination for immunogenicity study}

All mouse work was performed according to IACUC guidelines under UNC IACUC protocol ID 20-121.0. Vaccine studies were performed using BALB/c mice with free access to food and water. Mice were ordered from Jackson Laboratories and vaccinated at 8 weeks of age. Equal numbers of male and female mice were used per group, vaccinated subcutaneously with poly(I:C) (Sigma-Aldrich cat. \#P1530) or STING agonist $\mathrm{BI}-1387446$ alone as controls or in combination with 16 synthesized vaccine peptides, consisting of $480 \mu \mathrm{g}$ total peptide per vaccination (divided equimass per peptide, $30 \mu \mathrm{gs}$ each).

Control groups were $\mathrm{n}=3$ mice per group, and the peptide with adjuvant combinations were $n=6$ mice per group. $50 \mu \mathrm{g}$ of poly $(\mathrm{l}: \mathrm{C})$ was added to peptide mix or PBS control per vaccination. For the STING agonist BI-1387446 vaccinations, $10 \mu g$ s was diluted in 200uls of PBS, and injected in 50uls quantities to form a $1 \mathrm{~cm}$ square. Peptide mix or PBS control was injected within this $1 \mathrm{~cm}$ square. Mice were vaccinated on days 1 and 
8 , cheek bleeds obtained on days 8 and 15, and sacrificed with cardiac bleeds performed on day 22 .

\section{Peptide ELISA}

Serum obtained from cardiac bleeds on day 21 and cheek bleeds on experimental days 7 and 14 were tested for antibody response to the predicted B cell peptide epitopes used for vaccinations via peptide ELISAs. Plates were coated with $5 \mu \mathrm{g} / \mathrm{mL}$ of target peptide using coating reagent from the Takara Peptide Coating Kit (Takara cat. \#MK100). Measles peptide was utilized as a negative control, and Flag peptide was also plated as an experimental control. Plates were blocked with a blocking buffer according to the manufacturer's protocol. Serum was plated in duplicate wells with serial dilutions, and anti-FLAG antibody was plated in the experimental control wells. Rabbit anti-mouse IgG HRP (Abcam ab97046) was utilized as a secondary antibody. TMB substrate (Thermo Fisher Scientific cat. \#34028) was added, development was stopped with TMB Stop solution (BioLegend cat. \#423001), and plates were read at $450 \mathrm{~nm}$.

\section{Protein ELISA}

Serum obtained from cardiac bleeds on day 21 was utilized for ELISA testing for antibody response to SARS-CoV-2 spike (S) protein. Nunc Maxisorp plates (Thermo Fisher Scientific) were coated with $S$ protein (generously provided by Ting Lab at UNC), or BSA as a negative control and incubated overnight. Plates were blocked with $10 \%$ FBS in PBS, washed, and serum plated in duplicate wells with serial dilutions. 6x His Tagged monoclonal antibody (Thermo Fisher Scientific) was also plated as an experimental control. Goat anti-mouse IgG HRP (Thermo Fisher Scientific) was added to washed plates as a secondary antibody. TMB substrate (Thermo Fisher Scientific) was added, development was stopped with TMB Stop solution (BioLegend), and plates were read at $450 \mathrm{~nm}$.

\section{T-cell response quantification with ELISpot}

After the sacrifice of mice on experimental day 21, spleens were dissected out for ELISpot assessment of $\mathrm{T}$ cell activation in response to peptide and adjuvant vaccination. Spleens were mechanically dissociated using a GentleMACS Octo Dissociator (Miltenyi Biotec) and passed through a 70- $\mu$ m filter. RBC lysis buffer (Gibco cat. \#A1049201) was used to remove red blood cells, and cells were washed then passed through 40- $\mu \mathrm{m}$ filters. Splenocytes were counted and 250,000 splenocytes were plated per well into plates (BD Biosciences; cat. \#551083) that had been coated with each of the individual 16 predicted target peptides, or PBS as negative control or PHA as experimental control. Plates were incubated for $72 \mathrm{~h}$. Anti-interferon gamma 
detection antibody was added according to the manufacturer's protocol, followed by enzyme conjugate Streptavidin-HRP and final substrate solution (BD Biosciences; cat. \#557630). Plates were allowed to develop, washed to stop development, and allowed to dry before reading on ELISpot reader (AID Classic ERL07).

\section{Mouse vaccination for viral challenge}

Using the same IACUC protocol described above, female BALB/c mice were used, 5 per group. The groups consisted of the 16 synthesized vaccine peptides with poly(I:C) (Sigma-Aldrich cat. \#P1530), 16 synthesized vaccine peptides with STING agonist $\mathrm{BI}-1387446$, and PBS control group. Each mouse was vaccinated subcutaneously with $30 \mu \mathrm{gs}$ of each peptide, and $50 \mu \mathrm{gs}$ of poly(I:C) or $10 \mu \mathrm{gs}$ of STING agonist. Mice were vaccinated on days 1 and 8 , then transferred on day 22 for viral challenge assay.

\section{Live virus challenge}

Mice were lightly anesthetized with $50 \mathrm{mg} / \mathrm{kg}$ ketamine along with $15 \mathrm{mg} / \mathrm{kg}$ xylazine and were then intranasally inoculated with $10^{\wedge} 4$ pfu of SARS-CoV-2-MA10(27) diluted in 50uL PBS.

\section{Body weight and clinical scoring}

Body weights and clinical scores were recorded daily. Clinical disease was assessed using a 6-point scale(31): 0 = normal; 1 = piloerection; 2 = piloerection and kyphosis; 3 = piloerection, kyphosis, and reduced movement; 4 = piloerection, kyphosis, minimal spontaneous movement, +/- labored breathing (humane endpoint); 5 = moribund, dead, or euthanized. On 5 days post infection (DPI), mice were euthanized by an overdose of isoflurane anesthesia, and lungs were collected.

\section{Gross lung discoloration scoring}

Gross lung discoloration scores were assigned as follows(31): 0 = normal, pink lungs; 1 $=$ severe discoloration affecting less than $33 \%$ of the lung surface area or mild to moderate discoloration affecting less than $67 \%$ of the lung surface area; 2 = severe discoloration affecting $34 \%$ to $67 \%$ of the lung surface area or mild to moderate discoloration affecting $68 \%$ to $99 \%$ of the lung surface area; $3=$ severe discoloration affecting $68 \%$ to $99 \%$ of the lung surface area or mild to moderate discoloration affecting $100 \%$ of the lung surface area; and $4=$ severe discoloration affecting $100 \%$ of the lung surface area. 


\section{Results}

T-cells from mice vaccinated with either poly(l:C) or STING agonist as an adjuvant showed similar patterns of response but with significantly higher levels of activity for STING agonist. These responses were concentrated on peptides which had been selected for predicted T-cell immunogenicity, although one of six predicted B-cell targeting peptides also showed T-cell responses. Serum from vaccinated mice did not show meaningfully high levels of antibody binding to SARS-CoV-2 spike protein, indicating that either B-cell responses were not elicited or the linear epitopes targeted by vaccine peptides are not a good match for the conformational structure of spike. Though no neutralization study was performed, we can infer that neutralization without spike binding antibodies is extremely unlikely. Challenge of vaccinated mice with a murine adapted strain (SARS-CoV-2-MA10) demonstrated that elicited T-cell responses did not confer protection from infection or disease.

\section{Discussion}

At least three distinct scenarios may explain the lack of protection against severe disease despite strong virus specific T-cell responses in this study. One possibility is that in our particular model, BALB/c mice challenged with SARS-CoV-2-MA10, T-cell responses do not play any meaningful role in viral clearance independent of B-cells. Since related previous work has used different animals (e.g. K18-hACE2) and/or different viral strains (e.g. Wuhan-1), it is possible that lack of protection may be a peculiarity of our model.

Another possibility is that there is significant mismatch between SARS-CoV-2 T-cell epitopes and those of BALB/c mice infected with SARS-CoV-2-MA10. Our vaccine peptides were primarily selected for predicted human immunogenicity. Though we did screen candidate peptides for predicted murine MHC binding, the murine filtering was less stringent than HLA binding predictions. Additionally, human T-cell epitope predictions were not limited to just HLA binding but also included a more comprehensive model of immunogenicity trained on human T-cell epitopes curated from $\operatorname{IEDB}(32)$.

The last possibility is that T-cell responses do not, in general, play any protective role against SARS-CoV-2 in the absence of antibody responses. Due to the contradictions and ambiguity of previous animal studies and the limitations of this one, further research is required to disentangle these distinct interpretations. 


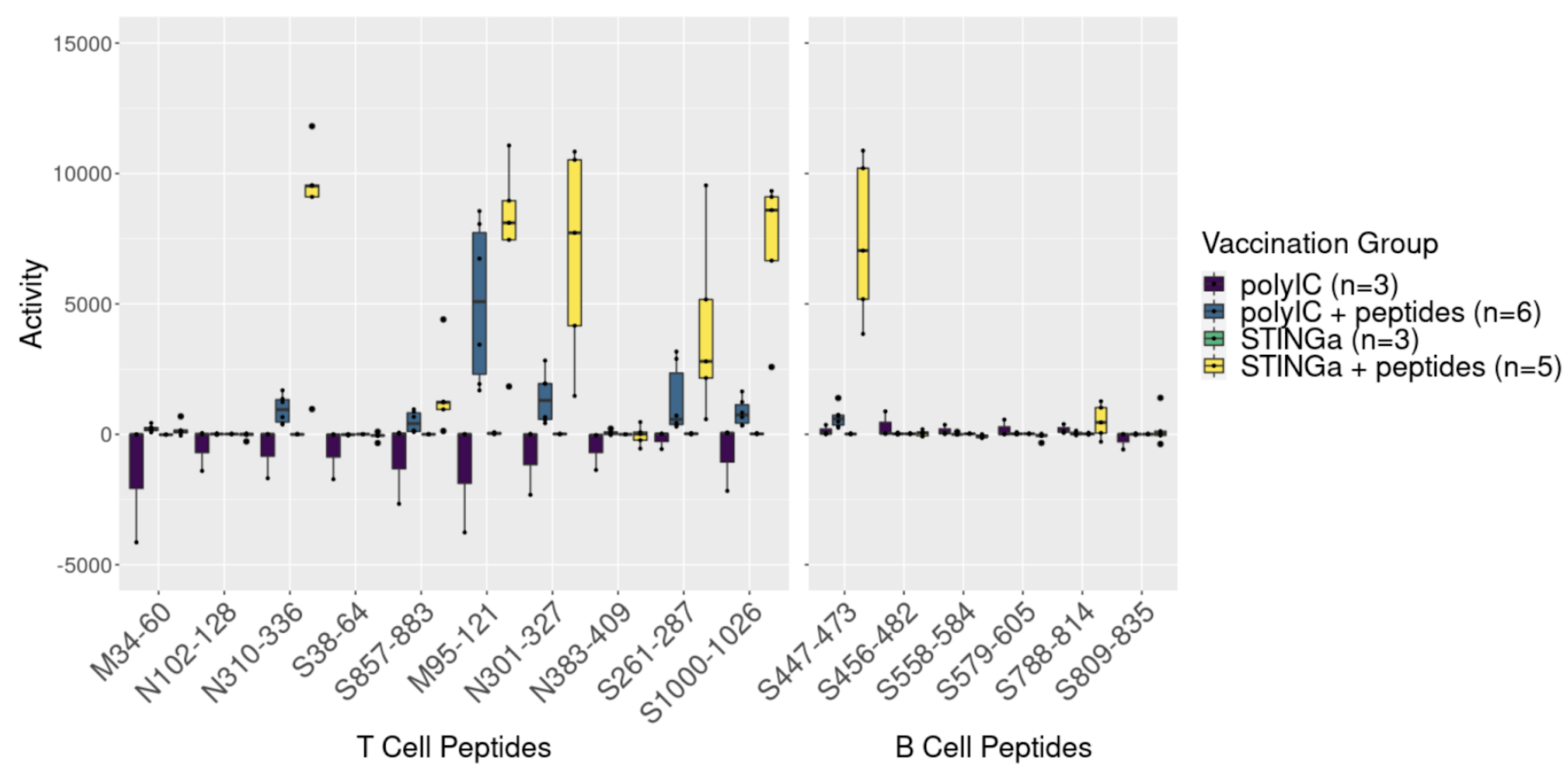

Figure 1. T-cell responses to individual vaccine peptides in BALB/c mice to vaccination with adjuvant only (polyIC, STINGa) and both adjuvants combined with peptides. Of the six peptides with noteworthy T-cell responses, five were included in the vaccine set for their predicted T-cell immunogenicity. The peptides with highest T-cell responses from STING agonist adjuvant also have the highest responses for the poly $(\mathrm{I}: \mathrm{C})$ group but poly $(\mathrm{I}: \mathrm{C})$ consistently attains order of magnitude lower responses. 


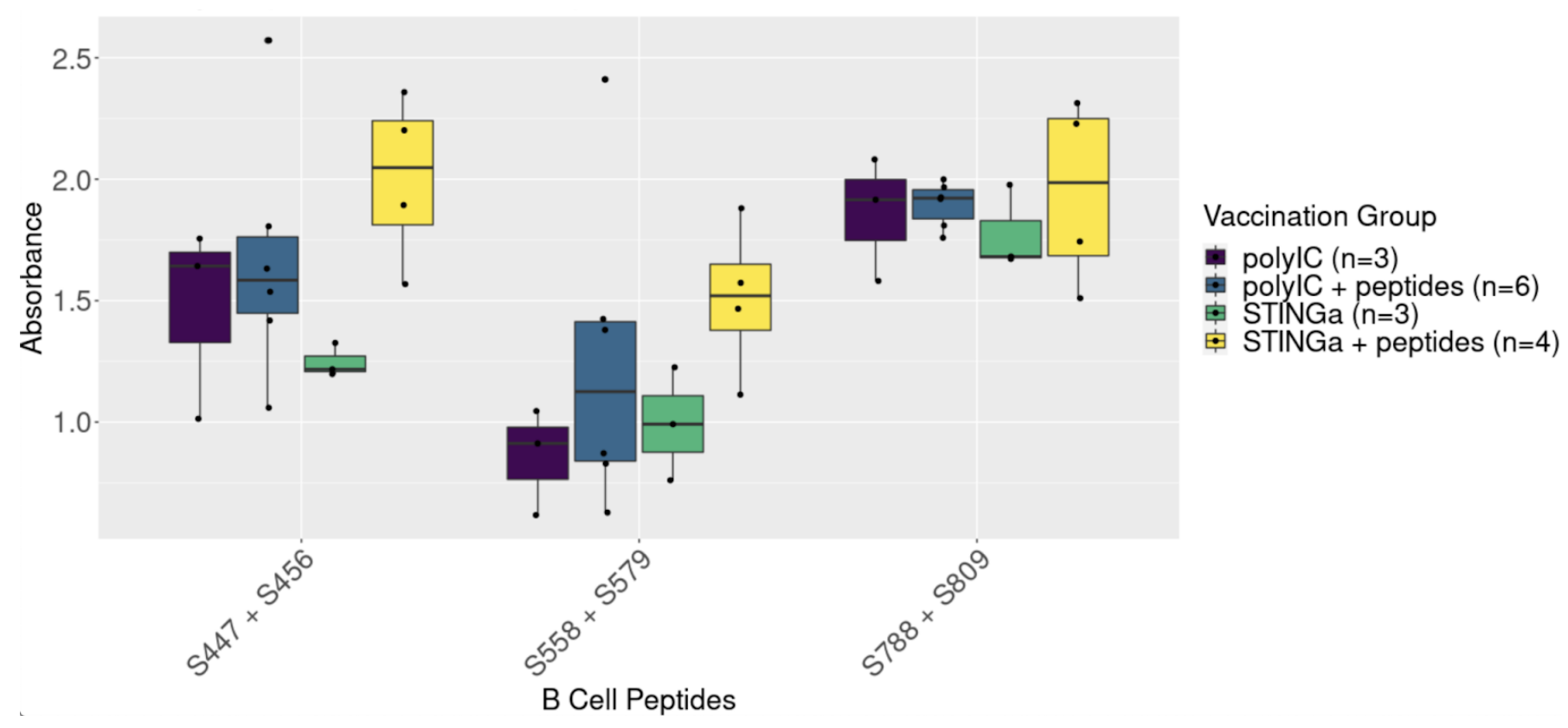

Figure 2. Antibody responses to pairs of vaccine peptides predicted to contain linear B-ecell epitopes in BALB/c mice after vaccination with adjuvant only (polyIC, STING) or adjuvant combined with peptides. While vaccination with poly $(\mathrm{l}: \mathrm{C})+$ peptides does not seem to meaningfully increase antibody responses against peptides, there is a meager increase over baseline when using the $\mathrm{BI}-1387446$ STING agonist as an adjuvant, especially in the pair of peptides overlapping an RBD derived B-cell epitope (S447 + S456). 


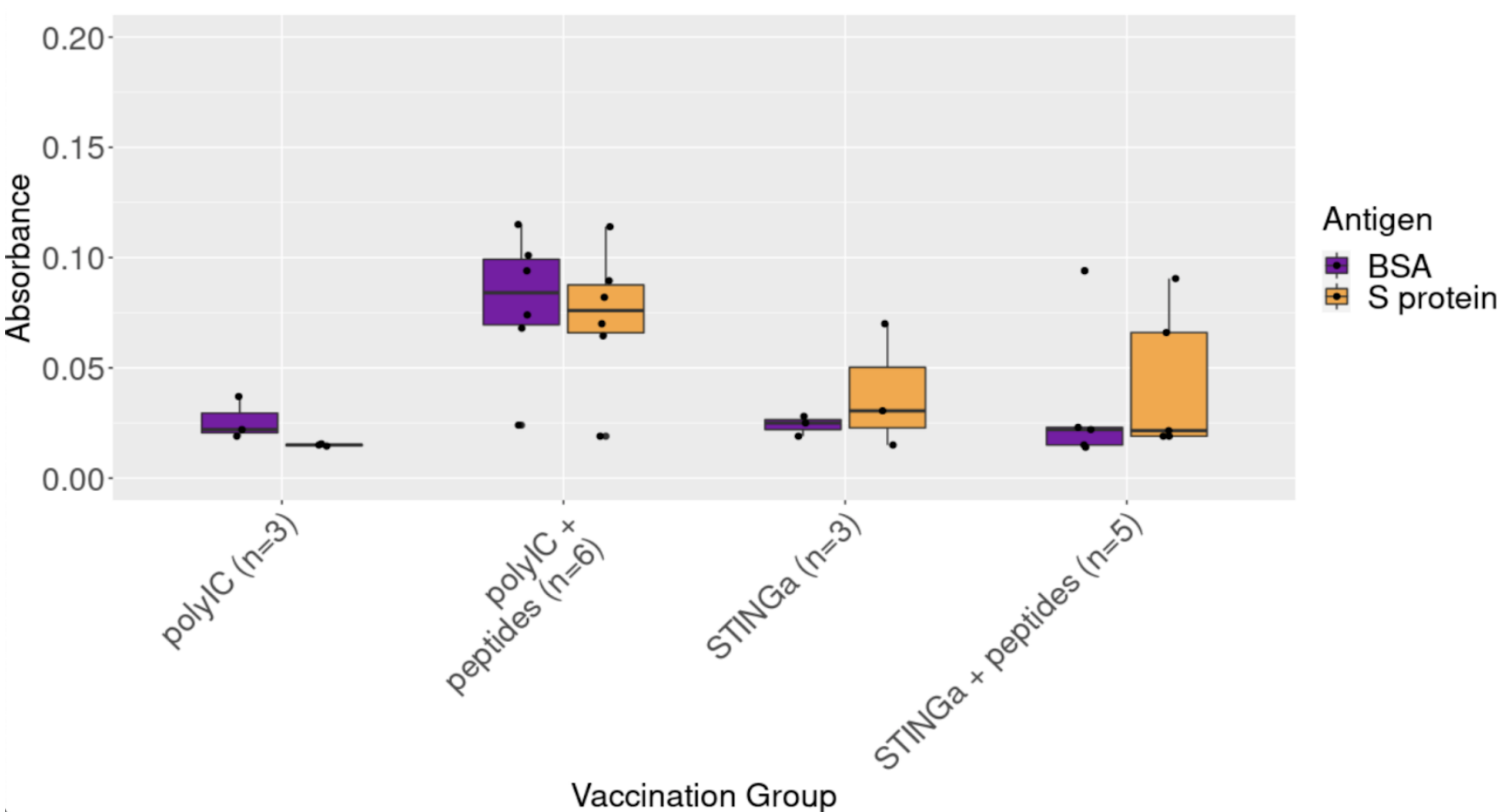

Figure 3. Antibody responses to SARS-CoV-2 spike protein in BALB/c mice after vaccination with adjuvant only (polyIC, STING) or adjuvant combined with peptides as measured by protein ELISA with either spike protein or a negative control (BSA). No group achieved significantly more antibody absorbance with spike protein as compared with BSA. 
A.
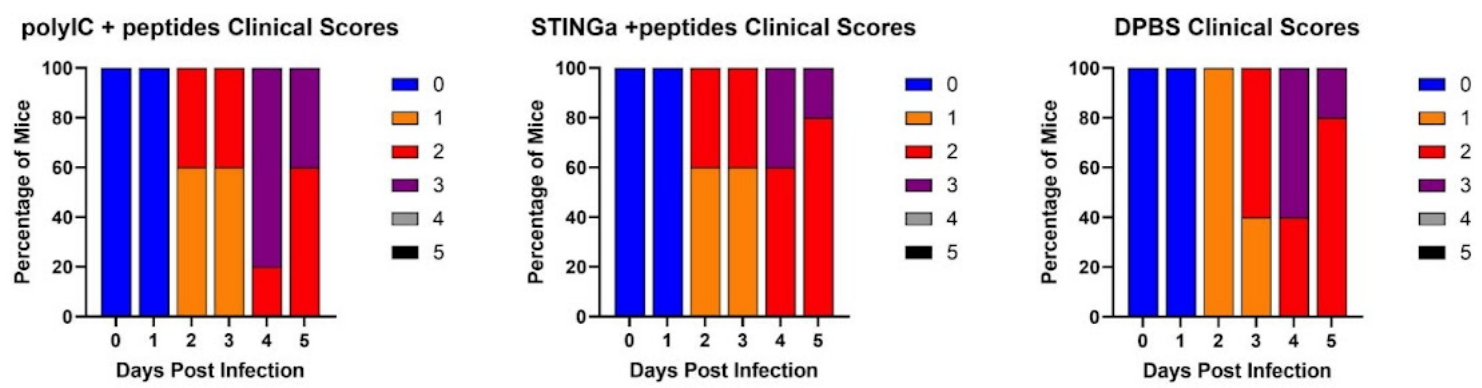

B.

\section{Body Weight}

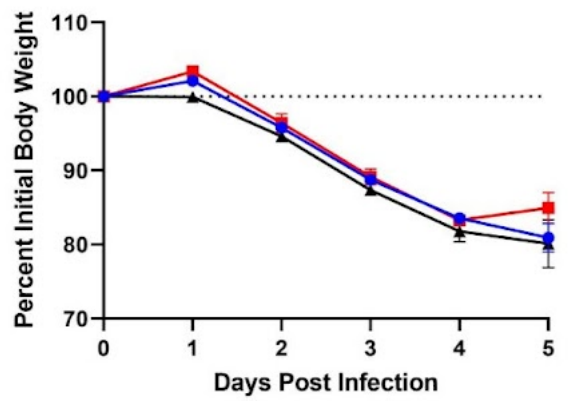

Gross Lung Discoloration

$\rightarrow$ polyIC + peptides

$\rightarrow$ STINGa + peptides

+ DPBS

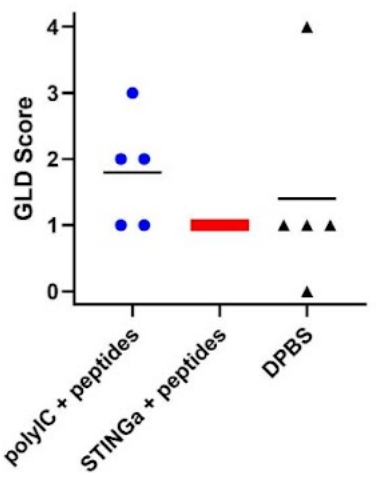

Figure 4. Lack of protection from infection or disease of BALB/C mice inoculated with SARS-CoV-2-MA10. Mice vaccinated with peptides and either poly(I:C) or STING agonist did not have statistically different clinical scores (A), loss of body weight (B) or gross lung discoloration $(\mathrm{C})$ compared with mice given a control. 


\section{Lung Titers}

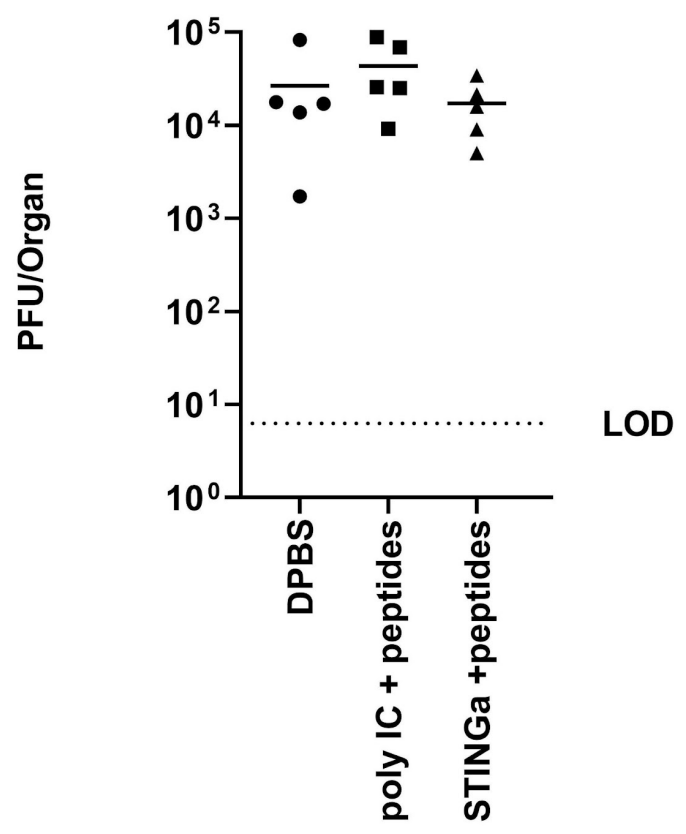

Figure 5. Viral titers in lungs of BALB/c mice after vaccination with one of poly(l:C) with vaccine peptides, STING agonist with vaccine peptides, or control, followed by challenge with SARS-CoV-2-MA10. There was no significant difference between groups. 


\section{References}

1. Giménez, E., E. Albert, I. Torres, M. J. Remigia, M. J. Alcaraz, M. J. Galindo, M. L. Blasco, C. Solano, M. J. Forner, J. Redón, J. Signes Costa, and D. Navarro. 2020.

SARS CoV 2 reactive interferon $\mathrm{Y}$ producing CD8+ T cells in patients hospitalized with coronavirus disease 2019. J. Med. Virol. 11: 30181.

2. Grifoni, A., D. Weiskopf, S. I. Ramirez, J. Mateus, J. M. Dan, C. R. Moderbacher, S. A.

Rawlings, A. Sutherland, L. Premkumar, R. S. Jadi, D. Marrama, A. M. de Silva, A. Frazier, A. F. Carlin, J. A. Greenbaum, B. Peters, F. Krammer, D. M. Smith, S. Crotty, and A. Sette. 2020.

Targets of T Cell Responses to SARS-CoV-2 Coronavirus in Humans with COVID-19 Disease and Unexposed Individuals. Cell 181: 1489-1501.e15.

3. Tarke, A., J. Sidney, C. K. Kidd, J. M. Dan, S. I. Ramirez, E. D. Yu, J. Mateus, R. da Silva Antunes, E. Moore, P. Rubiro, N. Methot, E. Phillips, S. Mallal, A. Frazier, S. A. Rawlings, J. A. Greenbaum, B. Peters, D. M. Smith, S. Crotty, D. Weiskopf, A. Grifoni, and A. Sette. 2021. Comprehensive analysis of $\mathrm{T}$ cell immunodominance and immunoprevalence of SARS-CoV-2 epitopes in COVID-19 cases. Cell Rep Med 2: 100204.

4. Francis, J. M., D. Leistritz-Edwards, A. Dunn, C. Tarr, J. Lehman, C. Dempsey, A. Hamel, V. Rayon, G. Liu, Y. Wang, and Others. 2021. Allelic variation in class I HLA determines CD8+ T cell repertoire shape and cross-reactive memory responses to SARS-CoV-2. Science Immunology eabk3070.

5. Baden, L. R., H. M. El Sahly, B. Essink, K. Kotloff, S. Frey, R. Novak, D. Diemert, S. A. Spector, N. Rouphael, C. B. Creech, J. McGettigan, S. Khetan, N. Segall, J. Solis, A. Brosz, C. Fierro, H. Schwartz, K. Neuzil, L. Corey, P. Gilbert, H. Janes, D. Follmann, M. Marovich, J. Mascola, L. Polakowski, J. Ledgerwood, B. S. Graham, H. Bennett, R. Pajon, C. Knightly, B. Leav, W. Deng, H. Zhou, S. Han, M. Ivarsson, J. Miller, T. Zaks, and COVE Study Group. 2021. Efficacy and Safety of the mRNA-1273 SARS-CoV-2 Vaccine. N. Engl. J. Med. 384: 403-416. 6. Polack, F. P., S. J. Thomas, N. Kitchin, J. Absalon, A. Gurtman, S. Lockhart, J. L. Perez, G. Pérez Marc, E. D. Moreira, C. Zerbini, R. Bailey, K. A. Swanson, S. Roychoudhury, K. Koury, P. Li, W. V. Kalina, D. Cooper, R. W. Frenck Jr, L. L. Hammitt, Ö. Türeci, H. Nell, A. Schaefer, S. Ünal, D. B. Tresnan, S. Mather, P. R. Dormitzer, U. Şahin, K. U. Jansen, W. C. Gruber, and C4591001 Clinical Trial Group. 2020. Safety and Efficacy of the BNT162b2 mRNA Covid-19 Vaccine. N. Engl. J. Med. 383: 2603-2615.

7. Voysey, M., S. A. Costa Clemens, S. A. Madhi, L. Y. Weckx, P. M. Folegatti, P. K. Aley, B. Angus, V. L. Baillie, S. L. Barnabas, Q. E. Bhorat, S. Bibi, C. Briner, P. Cicconi, E. A.

Clutterbuck, A. M. Collins, C. L. Cutland, T. C. Darton, K. Dheda, C. Dold, C. J. A. Duncan, K. R. W. Emary, K. J. Ewer, A. Flaxman, L. Fairlie, S. N. Faust, S. Feng, D. M. Ferreira, A. Finn, E. Galiza, A. L. Goodman, C. M. Green, C. A. Green, M. Greenland, C. Hill, H. C. Hill, I. Hirsch, A. Izu, D. Jenkin, C. C. D. Joe, S. Kerridge, A. Koen, G. Kwatra, R. Lazarus, V. Libri, P. J. Lillie, N. G. Marchevsky, R. P. Marshall, A. V. A. Mendes, E. P. Milan, A. M. Minassian, A. McGregor, Y. F. Mujadidi, A. Nana, S. D. Padayachee, D. J. Phillips, A. Pittella, E. Plested, K. M. Pollock, M. N. Ramasamy, A. J. Ritchie, H. Robinson, A. V. Schwarzbold, A. Smith, R. Song, M. D. Snape, E. Sprinz, R. K. Sutherland, E. C. Thomson, M. E. Török, M. Toshner, D. P. J. Turner, J. Vekemans, T. L. Villafana, T. White, C. J. Williams, A. D. Douglas, A. V. S. Hill, T. Lambe, S. C. Gilbert, A. J. Pollard, and Oxford COVID Vaccine Trial Group. 2021. Single-dose administration and the influence of the timing of the booster dose on immunogenicity and efficacy of ChAdOx1 nCoV-19 (AZD1222) vaccine: a pooled analysis of four randomised trials. Lancet 397: 881-891. 8. Noelle, R. J., and E. C. Snow. 1990. Cognate interactions between helper T cells and B cells. Immunol. Today 11: 361-368.

9. Hasenkrug, K. J., F. Feldmann, L. Myers, M. L. Santiago, K. Guo, B. S. Barrett, K. L. Mickens, 
A. Carmody, A. Okumura, D. Rao, M. M. Collins, R. J. Messer, J. Lovaglio, C. Shaia, R. Rosenke, N. van Doremalen, C. Clancy, G. Saturday, P. Hanley, B. J. Smith, K. Meade-White, W. L. Shupert, D. W. Hawman, and H. Feldmann. 2021. Recovery from Acute SARS-CoV-2 Infection and Development of Anamnestic Immune Responses in T Cell-Depleted Rhesus Macaques. MBio 12: e0150321.

10. McMahan, K., J. Yu, N. B. Mercado, C. Loos, L. H. Tostanoski, A. Chandrashekar, J. Liu, L. Peter, C. Atyeo, A. Zhu, E. A. Bondzie, G. Dagotto, M. S. Gebre, C. Jacob-Dolan, Z. Li, F. Nampanya, S. Patel, L. Pessaint, A. Van Ry, K. Blade, J. Yalley-Ogunro, M. Cabus, R. Brown, A. Cook, E. Teow, H. Andersen, M. G. Lewis, D. A. Lauffenburger, G. Alter, and D. H. Barouch. 2021. Correlates of protection against SARS-CoV-2 in rhesus macaques. Nature 590: 630-634. 11. Israelow, B., T. Mao, J. Klein, E. Song, B. Menasche, S. B. Omer, and A. Iwasaki. 2021. Adaptive immune determinants of viral clearance and protection in mouse models of SARS-CoV-2. Sci Immunol 6: eabl4509.

12. Matchett, W. E., V. Joag, J. M. Stolley, F. K. Shepherd, C. F. Quarnstrom, C. K. Mickelson, S. Wijeyesinghe, A. G. Soerens, S. Becker, J. M. Thiede, E. Weyu, S. D. O'Flanagan, J. A. Walter, M. N. Vu, V. D. Menachery, T. D. Bold, V. Vezys, M. K. Jenkins, R. A. Langlois, and D. Masopust. 2021. Cutting Edge: Nucleocapsid Vaccine Elicits Spike-Independent SARS-CoV-2 Protective Immunity. J. Immunol. 207: 376-379.

13. Wang, C. Y., T. Y. Chang, A. M. Walfield, J. Ye, M. Shen, S. P. Chen, M. C. Li, Y. L. Lin, M. H. Jong, P. C. Yang, N. Chyr, E. Kramer, and F. Brown. 2002. Effective synthetic peptide vaccine for foot-and-mouth disease in swine. Vaccine 20: 2603-2610.

14. Vázquez, S., M. G. Guzmán, G. Guillen, G. Chinea, A. B. Pérez, M. Pupo, R. Rodriguez, O. Reyes, H. E. Garay, I. Delgado, G. García, and M. Alvarez. 2002. Immune response to synthetic peptides of dengue prM protein. Vaccine 20: 1823-1830.

15. Amexis, G., and N. S. Young. 2007. Multiple antigenic peptides as vaccine platform for the induction of humoral responses against dengue-2 virus. Viral Immunol. 20: 657-663.

16. Conley, A. J., P. Conard, S. Bondy, C. A. Dolan, J. Hannah, W. J. Leanza, S. Marburg, M. Rivetna, V. K. Rusiecki, and E. E. Sugg. 1994. Immunogenicity of synthetic HIV-1 gp120 V3-loop peptide-conjugate immunogens. Vaccine 12: 445-451.

17. Bijker, M. S., C. J. M. Melief, R. Offringa, and S. H. van der Burg. 2007. Design and development of synthetic peptide vaccines: past, present and future. Expert Rev. Vaccines 6: 591-603.

18. Li, W., M. D. Joshi, S. Singhania, K. H. Ramsey, and A. K. Murthy. 2014. Peptide Vaccine: Progress and Challenges. Vaccines (Basel) 2: 515-536.

19. Melief, C. J. M., and S. H. van der Burg. 2008. Immunotherapy of established (pre)malignant disease by synthetic long peptide vaccines. Nat. Rev. Cancer 8: 351-360.

20. Supabphol, S., L. Li, S. P. Goedegebuure, and W. E. Gillanders. 2021. Neoantigen vaccine platforms in clinical development: understanding the future of personalized immunotherapy. Expert Opin. Investig. Drugs 30: 529-541.

21. Ammi, R., J. De Waele, Y. Willemen, I. Van Brussel, D. M. Schrijvers, E. Lion, and E. L. J. Smits. 2015. Poly(l:C) as cancer vaccine adjuvant: knocking on the door of medical breakthroughs. Pharmacol. Ther. 146: 120-131.

22. Kyi, C., R. L. Sabado, A. Blazquez, M. R. Posner, E. M. Genden, B. A. Miles, H. Khorasani, P. R. Dottino, H. Irie, E. R. Port, A. S. Wolf, H. J. Cho, S. S. Parekh, J. Mandeli, M. Galsky, W. K. Oh, S. Gnjatic, E. E. Schadt, P. A. Friedlander, and N. Bhardwaj. 2017. A phase I study of the safety and immunogenicity of a multipeptide personalized genomic vaccine in the adjuvant treatment of solid cancers. J. Clin. Orthod. 35: TPS3114-TPS3114.

23. Sabbatini, P., T. Tsuji, L. Ferran, E. Ritter, C. Sedrak, K. Tuballes, A. A. Jungbluth, G. Ritter, C. Aghajanian, K. Bell-McGuinn, M. L. Hensley, J. Konner, W. Tew, D. R. Spriggs, E. W.

Hoffman, R. Venhaus, L. Pan, A. M. Salazar, C. M. Diefenbach, L. J. Old, and S. Gnjatic. 2012. Phase I trial of overlapping long peptides from a tumor self-antigen and poly-ICLC shows rapid 
induction of integrated immune response in ovarian cancer patients. Clin. Cancer Res. 18: 6497-6508.

24. Hormigo, A., A. Rubinsteyn, J. Kodysh, A. Blazquez, and N. Bhardwaj. 2019. Abstract CT062: A Phase I study of the safety and immunogenicity of personalized mutation-derived tumor vaccine and treatment fields in patients with newly diagnosed glioblastoma. Cancer Res. 79: СT062-CT062.

25. Hart, M. K., K. J. Weinhold, R. M. Scearce, E. M. Washburn, C. A. Clark, T. J. Palker, and B. F. Haynes. 1991. Priming of anti-human immunodeficiency virus (HIV) CD8+ cytotoxic T cells in vivo by carrier-free HIV synthetic peptides. Proc. Natl. Acad. Sci. U. S. A. 88: 9448-9452. 26. Herst, C. V., S. Burkholz, J. Sidney, A. Sette, P. E. Harris, S. Massey, T. Brasel, E. Cunha-Neto, D. S. Rosa, W. C. H. Chao, R. Carback, T. Hodge, L. Wang, S. Ciotlos, P. Lloyd, and R. Rubsamen. 2020. An effective CTL peptide vaccine for Ebola Zaire Based on Survivors' CD8+ targeting of a particular nucleocapsid protein epitope with potential implications for COVID-19 vaccine design. Vaccine 38: 4464-4475.

27. Leist, S. R., K. H. Dinnon 3rd, A. Schäfer, L. V. Tse, K. Okuda, Y. J. Hou, A. West, C. E. Edwards, W. Sanders, E. J. Fritch, K. L. Gully, T. Scobey, A. J. Brown, T. P. Sheahan, N. J. Moorman, R. C. Boucher, L. E. Gralinski, S. A. Montgomery, and R. S. Baric. 2020. A Mouse-Adapted SARS-CoV-2 Induces Acute Lung Injury and Mortality in Standard Laboratory Mice. Cell 183: 1070-1085.e12.

28. Singh, S. K., M. Meyering, T. H. Ramwadhdoebe, L. F. M. Stynenbosch, A. Redeker, P. J. K. Kuppen, C. J. M. Melief, M. J. P. Welters, and S. H. van der Burg. 2012. The simultaneous ex vivo detection of low-frequency antigen-specific CD4+ and CD8+ T-cell responses using overlapping peptide pools. Cancer Immunol. Immunother. 61: 1953-1963.

29. Calvet-Mirabent, M., D. T. Claiborne, M. Deruaz, S. Tanno, C. Serra, C. Delgado-Arévalo, I. Sánchez-Cerrillo, I. de Los Santos, J. Sanz, L. García-Fraile, F. Sánchez-Madrid, A. Alfranca, M. Á. Muñoz-Fernández, T. M. Allen, M. J. Buzón, A. Balazs, V. Vrbanac, and E. Martín-Gayo. 2021. Poly I:C and STING agonist-primed DC increase lymphoid tissue polyfunctional HIV-1-specific CD8+ T cells and limit CD4+ T-cell loss in BLT mice. Eur. J. Immunol. . 30. Smith, C. C., K. S. Olsen, K. M. Gentry, M. Sambade, W. Beck, J. Garness, S. Entwistle, C. Willis, S. Vensko, A. Woods, M. Fini, B. Carpenter, E. Routh, J. Kodysh, T. O'Donnell, C. Haber, K. Heiss, V. Stadler, E. Garrison, A. M. Sandor, J. P. Y. Ting, J. Weiss, K. Krajewski, O. C. Grant, R. J. Woods, M. Heise, B. G. Vincent, and A. Rubinsteyn. 2021. Landscape and selection of vaccine epitopes in SARS-CoV-2. Genome Med. 13: 101.

31. Geng, Q., W. Tai, V. K. Baxter, J. Shi, Y. Wan, X. Zhang, S. A. Montgomery, S. A. Taft-Benz, E. J. Anderson, A. C. Knight, K. H. Dinnon 3rd, S. R. Leist, R. S. Baric, J. Shang, S.-W. Hong, A. Drelich, C.-T. K. Tseng, M. Jenkins, M. Heise, L. Du, and F. Li. 2021. Novel virus-like nanoparticle vaccine effectively protects animal model from SARS-CoV-2 infection. PLoS Pathog. 17: e1009897.

32. Kim, Y., J. Ponomarenko, Z. Zhu, D. Tamang, P. Wang, J. Greenbaum, C. Lundegaard, A. Sette, O. Lund, P. E. Bourne, M. Nielsen, and B. Peters. 2012. Immune epitope database analysis resource. Nucleic Acids Res. 40: W525-30. 